\title{
Alteration in protein contents and polypeptides of peanut plants due to herbicides and salicylic acid treatments
}

\author{
Khalaf Ali Fayez, ${ }^{1,2}$, Deya Eldeen Mohamed Radwan ${ }^{1}$, Asmaa Khalaf Mohamed ${ }^{1}$, Abdelrahman \\ Mahmoud Abdelrahmana ${ }^{1}$ \\ ${ }^{1}$ Botany Department, Faculty of Science, Sohag University, Egypt \\ ${ }^{2}$ Biology Department, Faculty of Science, Taif University, Saudi Arabia
}

Rec. 11 May, 2013 Accpt. 9 June, 2013

\begin{abstract}
The goal of the present study was to evaluate the protein contents and polypeptides of peanut cultivars (Arachis hypogaea L. cv. Giza 5 and Giza 6) under the influence of fusilade and basagran herbicides. The role of salicylic acid (SA) for alleviation the toxicity of herbicides was evaluated. After two weeks of treatments, the protein composition and polypeptides of peanut leaves compared to the control plants were analyzed. The results showed that increase concentrations of fusilade and basagran caused an increase in the insoluble and total protein contents of both leaf peanut cultivars. In contrast, the soluble protein of both cultivars showed variable contents depended on the herbicide concentration and cultivars. Spraying or mixed $1 \mathrm{mM}$ of salicylic acid with 1.5 recommended field dose (FD) of fusilade or basagran herbicides treated plants increased leaf total protein contents of peanut Giza 6 cultivar (G6) while that of Giza 5 cultivar (G5) was unaffected. The changes occurred in the polypeptides of G5 cultivar due to fusilade resulted in disappearance polypeptides of 14,41 and $42 \mathrm{kDa}$ and appearance a polypeptide of $32 \mathrm{kDa}$. In case of G6 cultivar, fusilade and basagran caused formation of polypeptides of 14 and $28 \mathrm{kDa}$. Basagran decreased the band intensity of most polypeptides in G5 cultivar but increased it in G6 cultivar compared with that of the control. The polypeptide of 41 $\mathrm{kDa}$ was highly accumulated with the interaction treatment of SA and herbicides.
\end{abstract}

Key words: Arachis hypogaea; Herbicides; Protein; Polypeptides; Salicylic acid

Abbreviations: FD, field dose; G5, Giza 5; G6, Giza 6; Mix, mixture; SA, salicylic acid; Sp, spray.

\section{Introduction}

In modern agronomic practices, herbicides are often used to control weeds and consequently to improve plant productivity. Nowadays, herbicides are used widely in agriculture, industry, and urban areas. However, the intensive and improper applications of herbicides led to their accumulation in soils and may deteriorate the quality of soil and water. Herbicides control or kill plants through a variety of mechanisms, including the inhibition of biological processes, such as photosynthesis, cell division, and root growth, interference with the synthesis of pigments, protein, and destruction of cell membranes (Hassanein et al., 1998; Fayez and Kristen, 1996; Fayez, 2000; Fayez, and Hassanein, 2000; Fayez and Abd- Elfattah, 2007; Xiang et al., 2013). Almost, $61 \%$ and $15 \%$ of total herbicides used worldwide in 2004 have been applied in North America and Europe, and Asia, respectively (Anonymous, 2006).

Peanut (Arachis hypogaea, Fabaceae), is an economically important food crop in many countries worldwide. It is native to South Africa, Mexico, South America and Mediterranean region. Weeds cause

\begin{tabular}{ll}
\hline * Corresponding author: & 27 \\
Dr. Khalaf Ali Fayez & \\
$\bowtie$ khalaffayez@yahoo.com &
\end{tabular}


tremendous damage to peanut yields (Richburg et al., 1994; Dotray and Keeling, 1997; Yu et al., 2007) and reduce peanut yield up to $75 \%$ (Gnanamurthy and Balasubramaniyan, 1998). The first three to four weeks of peanut growth period is critical for weed control (Kalaiselvan et al., 1991). Buchanan et al. (1982) suggested that peanut yields were not reduced when weeds were removed within the first three weeks after planting and when fields were kept weed-free throughout the rest of the season.

Fusilade is one of the systemic herbicides belongs to the Aryloxy-phenoxypropionates "FOPS" family of herbicides. The main target site of fusilade is the inhibition of acetyl coenzyme A carboxylase (ACCase) activity that catalyses the carboxylation of acetyl-CoA to malonyl-CoA (Abit and Al-Khatib, 2013; Nikolskaya et al., 1999, Yu et al., 2004). Basagran belongs to photosynthetic inhibitor herbicides blocking electron transport from photosystem II (PS II), resulting in photosynthesis inhibition and generation oxidative stress in sensitive plant species (Macedo et al., 2008; Reis et al., 2011). Basagran herbicide is extensively used in agriculture to replace atrazine (Hourmant et al., 2009).

Salicylic acid (SA) is a potent signaling molecule in plants and induces plant tolerance to various biotic and abiotic stresses (Horvath et al., 2007; Kazemi et al., 2010). It has been shown that SA provides protection against herbicides and oxidative stress (Rao et al., 1997; Popova et al., 2002; Ananieva et al., 2004; Fayez et al., 2011). It has been shown that SA provides protection against low temperature stress in maize (Janda et al., 1999) and salt stress condition (Arfan et al., 2007).

Protein metabolism of lupinus albus was altered in leaves followed carbetamide and metribuzin herbicides (Fernández-pascual, 1992). Inhibition of total leaf protein by herbicides was reported by Singh et al. (1984). The herbicide diclofop $\left\{2-\left[4\left(2^{\prime}, \quad 4^{\prime}-\right.\right.\right.$ dichlorophenoxy) phenoxy] propionic acid has been used by Hoppe and his associates, who have demonstrated that (a) that lipid synthesis was affected in root tips and leaves of sensitive species, (b) that the lipid effect was due to the inhibition of fatty acid synthesis de novo (and (c) that other metabolic reactions such as carbohydrate, nucleic acid and protein syntheses were not inhibited significantly (Hoppe, 1981; Hoppe and Zacher, 1982). Anabaena cylindrical cells exposed to 1.5 and $2 \mathrm{mM}$ of bentazon significantly increased cellular protein content (Galhano et al., 2009).

Electrophoretic SDS-protein profiles were successfully used to establish biochemical genetic finger prints of many plants (Abdel Salam et al., 1997a). Hussein and Salam (1985) stated that each band in the protein banding pattern of an organism reflects a separate transcriptional event. Electrophoretic analysis of the protein provides information concerning the structural genes and their regulatory systems that control the biosynthetic pathways of that protein, for example, herbicides caused many changes in the protein banding pattern of Glycine max (Fayez, 2000). Similar results were obtained by other investigators following different treatments (Abdel-Salam et al., 1997a; AbdelSalam et al., 1997b; Shehata et al., 2000). At molecular levels, the environmental stresses such as herbicides cause changes in protein metabolism and alterations in the protein polypeptides has been reported (Fayez, 2000).

Therefore, this work is an extensive study to show the effects of fusilade and basagran herbicides on leaf protein and polypeptides of peanut cultivars (Arachis hypogaea cv. Giza 5 and Giza 6). Furthermore, this work was to provide an evidence for the role of exogenous salicylic acid treatments in peanut plants against the effects caused by herbicide applications.

\section{Materials and methods: \\ Plant materials and treatments:}

Seeds of peanut cultivars (Arachis hypogaea, cv. Giza 5 and Giza 6), were kindly provided by the Agriculture Research Center, Ministry of Agriculture, Shandawil, Sohag, Egypt. The used herbicides were fusilade (fluzifop- $p$ - butyl) belongs to the aryloxyphenoxy propionate (Fops) and basagran (bentazon) belongs to the 
benzothiadiazinone group of herbicides. The two herbicides were commercially available and frequently used for weed control throughout the peanut fields. The herbicides used were applied by spraying to leaves until run off. Salicylic acid was used as sodium salicylate.

Seeds of the two peanut cultivars were sown in a mixture of soil and sand $(2: 1, \mathrm{v} / \mathrm{v})$ in clean plastic pots. Four weeks later, plants showed the same growth were chosen, divided into 12 groups and treated for two weeks as the following: Group 1, (Control, $\left.\mathrm{H}_{2} \mathrm{O}\right)$ plants was sprayed with water; Group 2, (Control, SA) plants sprayed with $1 \mathrm{mM}$ sodium salicylate; Group 3, (0.5 FD) plants sprayed with half field dose of fusilade; Group 4, (1 FD) plants sprayed with field dose of fusilade; Group 5, (1.5 FD) plants sprayed with 1.5 dose of fusilade; Group 6, (1.5 FD SA SP) plants sprayed with $1 \mathrm{mM}$ sodium salicylate one day before 1.5 field dose of fusilade treated; Group 7, (1.5 FD SA Mix) plants sprayed with the mixture of $1 \mathrm{mM}$ sodium salicylate +1.5 field dose of fusilade solution; Group 8, (0.5 FD) plants sprayed with half field dose of basagran; Group 9, (1 FD) plants sprayed with field dose of basagran; Group 10, (1.5 FD) plants sprayed with 1.5 normal dose of basagran; Group 11, (1.5 FD SA SP) plants sprayed with $1 \mathrm{mM}$ sodium salicylate one day before 1.5 field dose of basagran treated plants; Group 12, (1.5 FD SA Mix) plants sprayed with the mixture of $1 \mathrm{mM}$ salicylate + 1.5 field dose of basagran.

\section{Experimental methods:}

\section{Protein content estimation:}

According to Lowery et al. (1951) method, leaf protein contents were determined. Dry tissue samples $(0.1 \mathrm{~g})$ were extracted in $10 \mathrm{~mL}$ phosphate buffer $\mathrm{pH} 7.0$ for analysis of soluble protein. For total protein, $50 \mathrm{mg}$ of dry tissue was extracted in $10 \mathrm{~mL} \mathrm{NaOH}(0.1 \mathrm{~N})$ for $2 \mathrm{~h}$ at $90^{\circ} \mathrm{C}$. The extracts were centrifuged and the supernatants were collected. One $\mathrm{mL}$ of extract was added to $5 \mathrm{~mL}$ of alkaline reagent and mixed thoroughly then allowed to stand for $10 \mathrm{~min}$. A total of $0.5 \mathrm{~mL}$ of Folin phenol reagent diluted 1:1 (v/v) was then added and mixed immediately. After $30 \mathrm{~min}$, the extinction against appropriate blank was measured at $700 \mathrm{~nm}$. Results were expressed as $\mathrm{mg} / \mathrm{g}$ dry weight. Insoluble proteins were calculated as the difference between the amounts of total and water-soluble proteins. Bovine serum albumin was used for standard curve.

\section{Protein extraction and electrophoretic analysis:}

SDS-PAGE system of Laemmli (1970) was used with $24 \times 14 \times 0.2 \mathrm{~cm}$ vertical slab gels. The total proteins separated using separating gels contained $10 \%$ polyacrylamide. One gram of the plant leaves was ground on ice in a morter using $0.5 \mathrm{~mL}$ Tris- $\mathrm{HCl}$ and, protein samples were mixed with an equal volume of buffer containing 0.125 M Tris-HCl, (pH 6.6), $4 \%$ SDS, $20 \%$ glycerol, $10 \% \quad 2-$ mercaptoethanol and bromoiphenol blue as a tracking dye. The mixture was heated in a water bath at $40{ }^{\circ} \mathrm{C}$ for $30 \mathrm{~min}$ and then heated at $96{ }^{\circ} \mathrm{C}$ for $5 \mathrm{~min}$ and loaded onto gel wells for electrophoresis (Bio Rad, Protein II XI cell). Gels were then run at $18 \mathrm{~mA}$ per gel for $6 \mathrm{~h}$ at $4{ }^{\circ} \mathrm{C}$ in run buffer containing $0.025 \mathrm{M}$ Tris, $0.192 \mathrm{M}$ glycine and $0.1 \%$ SDS. Protein bands were visualized by $0.1 \%$ Commassie Brilliant Blue R.250 in the destain solution. Finally the gels were then destained in $40 \%$ (v/v) methanol, 7\% glacial acetic acid and 53 $\%$ distilled Water.

\section{Statistical analysis:}

The obtained data were tested for significance by using one-way of variance (ANOVA) test. Means were compared by least significant differences (LSD) test at levels $P<$ 0.05 and $P<0.01$. All statistical tests were carried out using SPSS (v. 9.0) software.

\section{Results: \\ Protein content:}

Soluble, insoluble and total proteins of control and treated peanut leaves were analyzed and shown in Tables 1 and 2. The most obvious changes were noticed in case of insoluble protein, while the soluble protein content was slightly affected in all treatments. Fusilade herbicide caused significant increase in protein contents of both cultivars. The application of fusilade caused a noticeable increase in leaf protein content regardless its 
applied dose. In G5 cultivar, with increasing fusilade field doses (0.5-1.5 FD), the insoluble and total proteins decreased but the values remain higher than the control. In contrast, the increase in insoluble and total proteins of G6 was concomitant with the increase of fusilade doses.

SA application (sprayed one day before fusilade or mixed with fusilade herbicide) stimulated G6 leaves to concentrate more proteins than G5 which became more or less similar to the corresponding control. In G6 cultivar, the leaves treated with the mixture of $1 \mathrm{mM} \mathrm{SA}+1.5 \mathrm{FD}$ of fusilade accumulate more proteins than those sprayed with $1 \mathrm{mM}$ $\mathrm{SA}$ one day before $1.5 \mathrm{FD}$ of fusilade.

On the other hand, application of basagran herbicide affected protein concentrations of G5 and G6 cultivars. Soluble protein of G5 leaves tend to decrease $(15 \%$ less than the control with using 1.5 FD of basagran), while the soluble protein of G6 leaves was unaffected in response to $1.5 \mathrm{FD}$ basagran spraying. Low dose of basagran enhanced the insoluble formation in both cultivars. Leaf total protein contents of both cultivars more or less unaffected due to application of 1 or 1.5 field dose of basagran herbicide. The most obvious increase was observed with the lowest dose of basagran (0. 5 FD). The leaf total protein content of both cultivars increased by 10\% (Tables 1 and 2). G6 cultivar was highly influenced by treatment with a mixed SA and basagran solution. The leaf total protein increased by $26.09 \%$ compared to that of the control. In comparison with the control, an induction of more insoluble and total proteins was detected as a result of spraying $1 \mathrm{mM} \mathrm{SA}$ in G5 leaves, while in G6 the SA had no significant effect (Tables 1 and 2).

\begin{tabular}{|c|c|c|c|c|c|c|c|c|c|c|c|c|c|}
\hline \multirow{2}{*}{ Herbicides } & \multirow{2}{*}{ Treatments } & \multicolumn{4}{|c|}{ Soluble } & \multicolumn{4}{|c|}{ Insoluble } & \multicolumn{4}{|c|}{ Total } \\
\hline & & $\mathbf{M}$ & \pm & SD & $\%$ & $\mathbf{M}$ & \pm & SD & $\%$ & $\mathbf{M}$ & \pm & SD & $\%$ \\
\hline & Control & 40.08 & \pm & 0.49 & 100 & 267.09 & \pm & 2.97 & 100 & 307.17 & \pm & 3.25 & 100 \\
\hline & Control SA & $31.50 *$ & \pm & 12.62 & 78.59 & $306.79 * *$ & \pm & 0.60 & 114.86 & $338.17 * *$ & \pm & 10.79 & 110.09 \\
\hline \multirow{5}{*}{ Fusilade } & $0.5 \mathrm{FD}$ & 44.57 & \pm & 2.38 & 111.20 & $321.77 * *$ & \pm & 8.76 & 120.47 & $366.33 * *$ & \pm & 10.25 & 119.26 \\
\hline & $1 \mathrm{FD}$ & 36.11 & \pm & 5.14 & 90.09. & $313.23 * *$ & \pm & 10.14 & 117.27 & $349.33 * *$ & \pm & 5.80 & 113.73 \\
\hline & $1.5 \mathrm{FD}$ & $31.79 *$ & \pm & 3.84 & 79.31 & $307.04 * *$ & \pm & 18.45 & 114.95 & $338.83 * *$ & \pm & 17.22 & 110.31 \\
\hline & $1.5 \mathrm{FD}+1 \mathrm{mM} \mathrm{SA} \mathrm{Sp}$ & 45.06 & \pm & 7.80 & 112.42 & 251.77 & \pm & 7.80 & 94.26 & 296.83 & \pm & 3.18 & 96.63 \\
\hline & $1.5 \mathrm{FD}+1 \mathrm{mM}$ SA Mix & 45.50 & \pm & 3.35 & 113.52 & 263.50 & \pm & 4.46 & 98.65 & 309.00 & \pm & 7.81 & 100.60 \\
\hline \multirow{5}{*}{ Basagran } & $0.5 \mathrm{FD}$ & 35.93 & \pm & 1.75 & 89.64 & $304.90 * *$ & \pm & 4.32 & 114.15 & $340.83 * *$ & \pm & 4.75 & 110.96 \\
\hline & $1 \mathrm{FD}$ & $31.06 *$ & \pm & 2.35 & 77.49 & $296.61 * *$ & \pm & 18.51 & 111.05 & $327.67 *$ & \pm & 21.99 & 106.67 \\
\hline & $1.5 \mathrm{FD}$ & $34.07 *$ & \pm & 2.20 & 85.00 & 262.60 & \pm & 11.63 & 98.32 & 296.67 & \pm & 11.12 & 96.58 \\
\hline & $1.5 \mathrm{FD}+1 \mathrm{mM} \mathrm{SA} \mathrm{Sp}$ & 37.22 & \pm & 1.58 & 92,86 & 278.11 & \pm & 6.12 & 104.11 & 315.33 & \pm & 7.64 & 102.66 \\
\hline & $1.5 \mathrm{FD}+1 \mathrm{mM} \mathrm{SA} \mathrm{Mix}$ & 36.28 & \pm & 14.91 & 90.52 & 277.39 & \pm & 12.53 & 103.85 & 313.67 & \pm & 8.75 & 102.12 \\
\hline
\end{tabular}

Table 1. Showed the effect of salicylic acid, fusilade, basagran and the interaction of salicylic acid + fusilade or basagran on protein content $\left(\mathrm{mg} \mathrm{g}^{-1} \mathrm{DW}\right)$ of Arachis hypogaea cv. Giza 5 leaves. Values are means $(\mathrm{M})$ of four replicates \pm standard deviation (SD).

Statistical significance of differences compared to control: *, significant at $P<0.05$; **, significant at $P<0.01$. 


\begin{tabular}{|c|c|c|c|c|c|c|c|c|c|c|c|c|c|}
\hline \multirow{2}{*}{ Herbicides } & \multirow{2}{*}{ Treatments } & \multicolumn{4}{|c|}{ Soluble } & \multicolumn{4}{|c|}{ Insoluble } & \multicolumn{4}{|c|}{ Total } \\
\hline & & M & \pm & SD & $\%$ & $\mathbf{M}$ & \pm & SD & $\%$ & M & \pm & SD & $\%$ \\
\hline & Control & 33.95 & \pm & 1.50 & 100 & 310.35 & \pm & 18.92 & 100 & 345.00 & \pm & 17.68 & 100 \\
\hline & Control SA & 27.30 & \pm & 4.70 & 80.41 & 301.95 & \pm & 7.88 & 97.29 & 329.17 & \pm & 2.25 & 95.41 \\
\hline \multirow{5}{*}{ Fusilade } & $0.5 \mathrm{FD}$ & 36.11 & \pm & 3.74 & 106.36 & 302.89 & \pm & 9.78 & 97.60 & 339.00 & \pm & 11.53 & 98.26 \\
\hline & $1 \mathrm{FD}$ & 28.99 & \pm & 8.68 & 85.40 & 323.18 & \pm & 14.57 & 104.13 & 352.17 & \pm & 5.97 & 102.08 \\
\hline & $1.5 \mathrm{FD}$ & 37.92 & \pm & 4.65 & 111.68 & $372.92 * *$ & \pm & 16.27 & 120.16 & $410.83 * *$ & \pm & 16.26 & 119.08 \\
\hline & $\begin{array}{l}1.5 \mathrm{FD}+1 \\
\mathrm{mM} \text { SA Sp }\end{array}$ & 37.45 & \pm & 3.32 & 110.31 & $353.36 * *$ & \pm & 1.43 & 113.86 & $391.25 * *$ & \pm & 6.01 & 113.41 \\
\hline & $\begin{array}{c}1.5 \mathrm{FD}+1 \\
\mathrm{mM} \text { SA Mix }\end{array}$ & 33.08 & \pm & 1.48 & 97.44 & $369.18 * *$ & \pm & 11.03 & 118.95 & $402.25 * *$ & \pm & 9.55 & 116.59 \\
\hline \multirow{5}{*}{ Basagran } & $0.5 \mathrm{FD}$ & 35.61 & \pm & 4.08 & 104.90 & $360.89 *$ & \pm & 10.06 & 116.28 & $387.50 *$ & \pm & 18.52 & 112.32 \\
\hline & $1 \mathrm{FD}$ & 42.88 & \pm & 0.49 & 126.29 & 306.38 & \pm & 16.83 & 98.72 & 349.25 & \pm & 17.32 & 101.23 \\
\hline & $1.5 \mathrm{FD}$ & 34.07 & \pm & 8.69 & 100.34 & 337.27 & \pm & 28.36 & 108.67 & 371.33 & \pm & 25.91 & 107.63 \\
\hline & $\begin{array}{l}1.5 \mathrm{FD}+1 \\
\mathrm{mM} \mathrm{SA} \mathrm{Sp}\end{array}$ & 39.20 & \pm & 0.99 & 115.46 & 301.80 & \pm & 18.10 & 97.25 & 343.83 & \pm & 14.36 & 99.66 \\
\hline & $\begin{array}{c}1.5 \text { FD + } 1 \\
\text { mM SA Mix }\end{array}$ & 36.49 & \pm & 10.77 & 107.47 & $398.51 * *$ & \pm & 4.40 & 128.41 & $435.00 * *$ & \pm & 6.36 & 126.09 \\
\hline
\end{tabular}

Table 2. Showed the effect of salicylic acid, fusilade, basagran and the interaction of salicylic acid + fusilade or basagran on protein content ( $\left.\mathrm{mg} \mathrm{g}^{-1} \mathrm{DW}\right)$ of Arachis hypogaea cv. Giza 6 leaves. Values are means (M) of four replicates \pm standard deviation (SD). Values are means $(\mathrm{M})$ of four replicates \pm standard deviation (SD).

Statistical significance of differences compared to control: *, significant at $P<0.05$; **, significant at $P<0.01$.

\section{Protein electrophoretic patterns:}

The following part is conducted to detect the protein patterns by using one-dimensional SDS-polyacrylamide Gel Electrophoresis (SDS-PAGE). Fusilade and basagran as well as SA treatments affected peanuts (Arachis hypogaea L. cv. G5 and G6) leaves showed various changes in protein polypeptides (Table 3 and Fig. 1). Appearance and disappearance of bands as well as a change in band intensities were recorded in comparison with that of the control plants.

\begin{tabular}{|c|c|c|c|c|c|c|c|c|c|}
\hline \multicolumn{9}{|c|}{ Giza 5 } & \multicolumn{7}{c|}{ Giza 6 } \\
\hline Control & F & F+SA & B & B+SA & Control & F & F+SA & B & B+SA \\
\hline 42 & - & 42 & 42 & 42 & $42(\mathrm{~L})$ & $42(\mathrm{H})$ & 42 & $42(\mathrm{H})$ & - \\
\hline 41 & - & 41 & 41 & $41(\mathrm{H})$ & $41(\mathrm{~L})$ & $41(\mathrm{H})$ & 41 & $41(\mathrm{H})$ & - \\
\hline $36(\mathrm{H})$ & 36 & $36(\mathrm{~L})$ & 36 & 36 & $36(\mathrm{~L})$ & $36(\mathrm{H})$ & 36 & 36 & $36(\mathrm{~L})$ \\
\hline $34(\mathrm{H})$ & 34 & $34(\mathrm{~L})$ & 34 & 34 & $34(\mathrm{~L})$ & $34(\mathrm{H})$ & 34 & 34 & $34(\mathrm{~L})$ \\
\hline- & 32 & - & - & 32 & - & - & - & - & - \\
\hline- & - & 28 & - & 28 & - & 28 & - & 28 & - \\
\hline 21 & 21 & 21 & 21 & 21 & 21 & 21 & 21 & 21 & $20(\mathrm{~L})$ \\
\hline $18(\mathrm{H})$ & 18 & 18 & 18 & 18 & 18 & 18 & 18 & 18 & $18(\mathrm{~L})$ \\
\hline $17(\mathrm{H})$ & $17(\mathrm{H})$ & $17(\mathrm{H})$ & 17 & $17(\mathrm{H})$ & 17 & $17(\mathrm{H})$ & 17 & $17(\mathrm{H})$ & $17(\mathrm{~L})$ \\
\hline $14(\mathrm{H})$ & - & 14 & $14(\mathrm{H})$ & 14 & - & $14(\mathrm{H})$ & - & $14(\mathrm{H})$ & - \\
\hline $11(\mathrm{H})$ & $11(\mathrm{H})$ & 11 & 11 & 11 & 11 & $11(\mathrm{H})$ & 11 & 11 & $11(\mathrm{~L})$ \\
\hline
\end{tabular}

Table 3. Relatively molecular weights of protein polypeptides detected in Arachis hypogaea cv. Giza 5 and Giza 6 treated with salicylic acid, fusilade, basagran and the interaction of salicylic acid + fusilade or basagran. Data were obtained by one- dimensional SDS-polyacrylamide Gel Electrophoresis (SDS-PAGE). Where B, F, H, L and SA letters are refer to the basagran, fusilade, high band density, less band density and salicylic acid, respectively. 


\section{Protein patterns of Giza 5 cultivar:}

The changes in protein pattern of G5 leaves in response to treatments were shown in Figure 1 (Lanes 1, 2, 3, 4 and 5) and presented in details in Table 3. In comparison between peanut cultivars, the polypeptides of untreated plants of G5 cultivar had higher intensity than in G6 cultivar. Untreated G5 showed a polypeptide of about $18 \mathrm{kDa}$ (Fig. 1) which was absent in G6. Comparing with the control, application of the highest dose (1.5 FD) of fusilade to G5 leaves led to formation a new polypeptide of about $32 \mathrm{kDa}$ and disappeared of polypeptides with the molecular weight of 14,41 and $42 \mathrm{kDa}$. The intensity of polypeptides of 18,34 and $36 \mathrm{kDa}$ decreased in response to fusilade application. SA spraying one day before fusilade application caused formation of 28 and accumulation of $41 \mathrm{kDa}$ polypeptides.

Basagran treated G5 leaves decreased the intensity of most polypeptides (Lane 4) in comparison with that of the control (Lane 1). In response to $1 \mathrm{mM} \mathrm{SA}$ spraying before one day of basagran application, the polypeptides of 28 and $32 \mathrm{kDa}$ were formed. On the other hand, SA spraying increased intensity of polypeptides of about 11,17 and $41 \mathrm{kDa}$, in comparison with that of basagran treated plants.

\section{Protein patterns of Giza 6 cultivar:}

It was noted that the protein bands in G6 had lower intensity than in G5 (Fig. 1). Application of fusillade (1.5 FD) caused formation of polypeptides of about 14 and 28 $\mathrm{kDa}$. Furthermore, the density of polypeptides of about 11, 18, 21, 34, 36 and $41 \mathrm{kDa}$ increased in comparison with the control. In response to SA Spraying before one day of fusilade application (avoid alterations in polypeptides which were resulted in plants treated only with fusilade (Lane 8). The profile polypeptides (Lane 7) appear to be as that of control plants (Lane 6).

Effects of basagran herbicide (1.5 FD) on polypeptides of G6 (Fig. 1) are shown in lane 9. Band intensities of basagran treated plants were stained greatly when compared with that of the control (Lane 6), especially bands of 17, 41 and $42 \mathrm{kDa}$. As the fusilade effect, basagran treatment led to a formation of polypeptides of 14 and $28 \mathrm{kDa}$. SA spraying to plants before one day of basagran resulting in weakly stained polypeptides.

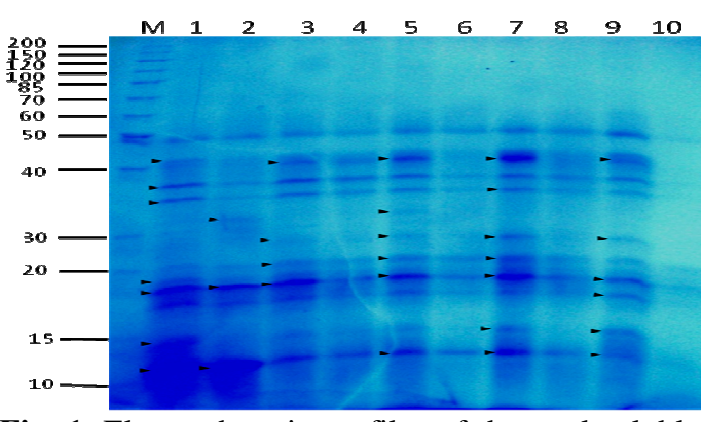

Fig. 1. Electrophoretic profiles of the total soluble proteins extracted from leaves of peanut (Arachis hypogaea cv. Giza 5 and Giza 6) after two weeks of being treated with fusilade, basagran and salicylic acid (SA) compared to the control. Giza 5 control (lane 1); fusillade (lane 2); fusilade + SA (lane 3), basagran (line 4); basagran + SA (line 5); Giza 6 control (line 6); fusilade (lane 7); fusilade + SA (lane 8), basagran (line 9); basagran + SA (line 10). Polypeptide bands were visualized by Coomassie blue. Acrylamide slab gel was photographed. Arrow-heads refer to polypeptides that were altered.

\section{Discussion:}

The major function of proteins in metabolism is to serve as enzymes for metabolic activities (Hoppe, 1981). In this experiment, with all herbicides treatments, the most obvious changes were noticed in case of insoluble and total proteins, while the soluble protein content was slightly affected. Fusilade application caused a noticeable increase in protein contents in both cultivars. The increase of G6 insoluble and total proteins was fusilade dose-dependent. Under herbicide stress, the stimulation of protein synthesis that led to protein accumulation is involved in sequences that the enzymes activity rises as defense mechanism against herbicide stress (Peixoto $e t$ al., 2008). Moreover, the observed increase in the protein content, through treatment with herbicides, was likely the result of a loss of water and electrolytes from the cell rather than an increase of the protein synthesis (Peixoto $e t$ al., 2008). Other opinions suggest protein accumulation under herbicidal stress is due to rapid synthesis or less degradation of proteins (Ries, 1967). 
On the other side, basagran application caused decrease in soluble protein levels in G5 leaves while G6 was unaffected. Similar to fusilade, basagran enhanced the insoluble and total proteins formation in both cultivars. Previous reports demonstrated that bentazon (basagran) doses increased cellular protein content of A. cylindrical (Galhano, 2009). Furthermore, Kobbia et al., (2001), droved an explanation, he reported that photosynthetic inhibitors enhanced cellular nitrogen metabolism thus leading to more amino acid and protein accumulation in cells.

SA acts as a scavenger of some ROS (e.g. $\mathrm{OH})$ but its signaling pathways also rely on interactions with SA-binding proteins and with various oxidases, peroxidases and catalase involved in generation and removal of ROS (Fayez and Bazaid, 2013; Garcion and Métraux, 2006). Contrary, other researchers reported that bentazon (basagran) secondary effects are inhibition of RNA, proteins and lipids synthesis (Al-Mendoufi and Ashton, 1984; Han and Wang, 2002).

SA application (sprayed before or mixed with fusilade herbicide) stimulated G6 leaves to concentrate more proteins than G5, which became more or less similar to the control and SA mixed with basagran recorded the maximum increase for insoluble and total proteins. Also a gradual increase in the total protein content of Sunflower (Helianthus annuus L) after SA application was observed by Çag (2009). Contrary for this data, a reduction in soluble protein content in waterstressed wheat plants with SA application was detected (Singh and Usha, 2003). This suggested that SA may be in turn, represent stressful factor other than the herbicide on plant.

In the experiment of protein polypeptides, application of fusilade to leaves of Giza 5 cultivar (G5) led to formation of a new polypeptide of about $32 \mathrm{kDa}$. As stated in the results, polypeptides with the molecular weight of 14,41 and $42 \mathrm{kDa}$ of G5 were disappeared due to fusilade treatments. The intensity of polypeptides of 18,34 and $36 \mathrm{kDa}$ decreased. Pfister et al. (1981), using the azidoatrazine, have identified a 32-kD polypeptide as the herbicide-binding protein in chloroplast membranes. They suggest that this $32-\mathrm{kD}$ protein is the binding protein for all PSII inhibitors. Suggesting that, this protein with an apparent of $32 \mathrm{kDa}$, is the herbicidebinding protein. Basagran application decreased the intensity of most polypeptides. In G6, the application of fusilade caused formation of polypeptides of about 14 and 28 $\mathrm{kDa}$; and the density of polypeptides of about $11,18,21,34,36$ and $41 \mathrm{kDa}$ increased in comparison with the control.

Spraying SA before one day of fusilade application avoids alterations in polypeptides which were resulted in plants treated only with fusilade. On this, the polypeptide profiles appear to be as that of the control plants. SA spraying before one day of basagran application, led to formation polypeptides of 28 and $32 \mathrm{kDa}$. It is clear that basagran, caused the intensities of band were stained greatly when compared with that of the control, especially bands of 17,41 and 42 $\mathrm{kDa}$, and formation of basagran of polypeptides of 14 and $28 \mathrm{kDa}$. D1 protein is characterized a very rapid turnover in light (Mattoo et al., 1984) which is accumulates with increasing light intensity (Schuster $e t$ al., 1988) and PSII inhibitors (Fayez, 2000). On the other hand, the total soluble protein content of root tips in maize seedlings, as an important indicator of reversible or irreversible changes in metabolism, exhibited a positive correlation with 2,4-D concentration (Aksakal, et al., 2013).

\section{Acknowledgements:}

This work was supported by Faculty of Science, Sohag University, Egypt.

\section{References:}

Abdel Salam, A.Z.E., Hassan, H.Z., Soliman, A., Bahieldin, A. (1997a). Differential mutagenic activities of two aromatic compounds due to different side chain as revealed by cytological analysis and biochemical genetic indices. Egypt. J. Genet. Cytol. 26:121-142.

Abdel Salam, A.Z.E., Soliman, A. Hassan, H.Z. (1997b). The mutagenic potentialities of two organo phosphorus compound using different biological systems .Egypt .J .Genet. Cytol. 26:105-120. 
Abit, M.J.M., Al-Khatib, K. (2013). Metabolism of quizalofop and rimsulfuron in herbicide resistant grain sorghum. Pest. Biochem. Physiol.105:24-27.

Aksakal, O., Aygun Erturk, F., Sunar, S., Bozari, S., Agar, G. (2013). Assessment of genotoxic effects of 2,4dichlorophenoxyacetic acid on maize by using RAPD analysis. Indus. Crops Prod. 42:552-557.

Al-Mendoufi, O., Ashton, F.M. (1984). Bentazon influence on selected metabolic processes of isolated bean leaf cells. J. Plant Growth Regul. 3:121126.

Ananieva, E.A., Christov, K.N., Popova, L.P. (2004). Exogenous treatment with salicylic acid leads to increased antioxidant capacity in leaves of barley plants exposed to paraquat. J. Plant. Physiol. 161:319-328.

Anonymous, (2006). Crop Protection Handbook. Meister Publishing Company, Ohio.

Arfan, M., Athar, H.R., Ashraf, M. (2007). Does exogenous application of salicylic acid through the rooting medium modulate growth and photosynthetic capacity in two differently adapted spring wheat cultivars under salt stress? J. plant physiol. 64:685-694.

Buchanan ,G.A., Murray, D.S., Hauser, E.W. (1982).Weeds and their control in peanuts. In, H.E. Pattee and C.T. Young, eds., Peanut Science and Technology. pp. 209-249, American Peanut Research Education Society, Yoakum, Tex, USA.

Çag, S., Cevahir-öz, G., Sarsag, M., GörenSaglam, N. (2009). Effect of salicylic acid on pigment, protein content and peroxides activity in excised sunflower cotyledon. Pak. J. Bot. 41:2297-2303.

Dotray, P.A., Keeling, J.W. (1997). Purple nutsedge control in peanut as affected by imazameth and imazethapyr application timing. Peanut Sci. 24:113116.

Fayez, K.A. (2000). Action of photosynthetic diuron herbicide on cell organelles and biochemical constituents of the leaves of two soybean cultivars. Pest. Biochem. Physiol. 66: 105-115.
Fayez, K.A., Abd- Elfattah, Z. (2007). Alteration in growth and physiological activities in Chlorella vulgaris under the effect of photosynthetic inhibitor diuron. Int. J. Agri. Biol. 9:631-634.

Fayez, K.A., Bazaid, S.A. (2013). Improving drought and salinity tolerance in barley by application of salicylic acid and potassium nitrate. J. Saudi Soc. Agric. Sci. In Press.

Fayez, K.A., Hassanein A.M. (2000). Chlorophyll synthesis retardation and ultrastructural alterations to Solanum tuberosum chloroplasts in Solanum nigrum cells. Photosynthetica. 38:3744.

Fayez, K.A., Kristen, U. (1996). The influence of herbicides on the growth and proline content of primary roots and on the ultrastructure of root caps. Environ. Exp. Bot. 36:71-81.

Fayez, k.A., Radwan, D.E.M., Mohamed, K.A., Abdelrahman, M.A. (2011). Herbicides and salicylic acid applications caused alterations in total amino acids and proline contents of peanut cultivars. J. Environ. Stu. 6:55-61.

Fernández-pascual, M., Lorenzo, C., Pozuelo, J.M., Felipe, R. (1992). Alterations induced by four herbicides on lupine nodule cortex structure, protein metabolism and some senescencerelated enzymes. J. plant physiol. 140:385-390.

Galhano, V., Peixoto, F., Gomes-Laranjo, J., Fernández-Valiente, E. (2009). Differential Effects of Bentazon and Molinate on Anabaena cylindrica, an Autochthonous Cyanobacterium of Portuguese Rice Field Agro-ecosystems. Water Air Soil Poll. 197:211-222.

Garcion, C., Métraux, J.P. (2006). Salicylic acid, Annu. Plant Rev. 24:229-255.

Gnanamurthy, P., Balasubramaniyan, P. (1998). Weed management practices and their influence on weed growth and yield of groundnut. Indian J. Agron. 43:122125.

Han, Y.C., Wang, C.Y. (2002). Physiological basis of bentazon tolerance in rice (Oryza sativa L.) lines. Weed Biol. Manag. 2:186-193. 
Hassanein, A.M., Fayez, K.A., Ahmed, A.M. (1998). Physiological studies on nuclear-organelle interaction of cybrid plants containing Solanum nigrum genome and Solanum tuberosum plastome, Phyton (Horn, Austria) 37:167-179.

Hoppe, H.H. (1981). Einflu, von Diclofopmethyl auf die Protein-, Nukleinsaure und Lipid biosynthese der Keimwurzelspitzen von Zea mays L. Z Pflanzen physiol. 102:189-197.

Hoppe, H.H., Zacher, H. (1982). Hemmung der Fetts \& urebiosynthese durch Diclopfop-methyl in Keimwurzelspitzen von Zea mays. Z. Pflanzenphysiol. 106:287-298.

Horvath, E., Szalai, G., Janda, T. (2007). Induction of abiotic stress tolerance by salicylic acid signaling. J. Plant Growth Regul. 26:290-300.

Hourmant, A., Amara, A., Pouline, P., Durand, G., Arzul, G., Quiniou, F. (2009). Effect of bentazon on growth and physiological responses of marine diatom: Chaetoceros gracilis. Toxicol. Mechan. Methods. 19:109-115.

Hussein, E. H. A., Salam, A. Z. (1985). Evolutionary relationship among Vicia faba species as revealed by electrophoretic studies. Egypt. J. Cytol. 14:197-211.

Janda,T., Szalai. G., Tari, I., Páldi, E. (1999). Hydroponic treatment with salicylic acid decreases the effects of chilling injury in maize (Zea mays L.) plants. Planta. 208:175-180.

Kalaiselvan, P., Ramadas, G.R., Vaman, B.M. (1991). Studies on crop weed competition in groundnut. Madras Agric. J. 78:385-388.

Kazemi, N., Khavari-Nejad, R.A., Fahimi, H., Saadatmand, S., Nejad-Sattari, T. (2010). Effects of exogenous salicylic acid and nitric oxide on lipid peroxidation and antioxidant enzyme activities in leaves of Brassica napus L. under nickel stress. Sci. Hortic. 126:402-407.

Kobbia, I. A., Battah, M. G., Shabana, E. F., Eladel, H. M. (2001). Chlorophyll a fluorescence and photosynthetic activity as tools for the evaluation of simazine toxicity to Protosiphon botryoides and Anabaena variabilis. Ecotox. Environ. Saf. 49:101-105.

Laemmli, U.K. (1970). Cleavage of structural proteins during the assembly of the head of bacteriophage $T_{4}$. Nature. 227:680685.

Lowery, O. H., Rosebrough, N. J., Farr A. I., Randall, R. J. (1951). Protein measurement with the folin phenol reagent. J. Biol. Chem. 193:291-297.

Macedo, R.S., Lombardi, A.T., Omachi, C.Y., Rorig, L.R. (2008). Effects of the herbicide bentazon on growth and photosystem II maximum quantum yield of the marine diatom Skeletonema costatum. Toxicol. In vitro. 22:716-722.

Mattoo, A. K., Hoffman-Falk H., Marder J., Edelman M. (1984). Regulation of protein metabolism: coupling of photosynthetic electron transport to in vivo degradation of the rapidly metabolized 32-kilodalton of chloroplast membranes. Proc. Natl. Acad. Sci. USA, 81:1380-1384.

Nikolskaya, T., Zagnitko, O., Tevzadze, G., Haselkorn, R., Gornicki, P. (1999). Herbicide sensitivity determinant of wheat plastid acetyl-CoA carboxylase is located in a 400-amino acid fragment of the carboxyl transferase domain. Proc. Natl. Acad. Sci. USA. 96:14647-14651.

Peixoto, F.P., Gomes-Laranjo, J., Vicente, J.A., Madeira, V.M.C. (2008). Comparative effects of the herbicides dicamba, 2,4-D and paraquat on non-green potato tuber calli. J. Plant Physiol. 165:1125-1133.

Pfister, K., Steinback, K.E., Arntzen, C.J., Gardner, G. (1981). Photoaffinity labeling of an herbicide receptor protein in chloroplast membranes. Proc. Natl. Acad. Sci. USA. 78: 981-985.

Popova, L.P., Ananieva, E.A., Alexieva, V.S. (2002). Treatment with salicylic acid decreases the effects of paraquat on Photosynthesis. J. Plant Physiol. 159: 685-693.

Rao, M.V., Paliyath, G., Ormrod, D.P., Murr, D.P., Watkins, C.B. (1997). Influence of salicylic acid on $\mathrm{H}_{2} \mathrm{O}_{2}$ production, oxidative stress, and $\mathrm{H}_{2} \mathrm{O}_{2}$ metabolizing enzymes (Salicylic Acid-Mediated 
Oxidative Damage Requires $\mathrm{H}_{2} \mathrm{O}_{2}$ ). Plant Physiol.115: 137-149.

Reis, M.O., Necchi, Jr. O., Colepicolo, P., Barros, M.P. (2011). Co-stressors chilling and high light increase photooxidative stress in diuron treated red alga Kappaphycus alvarezii but with lower involvement of $\mathrm{H}_{2} \mathrm{O}_{2}$. Pest. Biochem. Physiol. 99:7-15.

Richburg, I.J.S., Wilcut, J.W., Whetje, G.R. (1994). Toxicity of AC263222 to purple and yellow nutsedge. Weed Sci. 42:398-402.

Ries, S. K., Chmiel, H., Dilley, D. R., Filner, P. (1967). The increase in nitrate reductase activity and protein content of plants treated with simazine. Proc. Natl. Acad. Sci. USA. 58:526-532.

Schuster, G., Timberg, R., Ohad, I. (1988). Turnover of thylakoid photosytem II proteins during photoinhibition of chlamydomonas reinhardli. Eur. J. biochem. 177:403-410.

Shehata, M.M., Habib, A., Khalifa, N.S., Salama, M.S. (2000). Cytological and biochemical effect of 5-Florouracil and colchicine of Vicia faba plants Egypt .J. Biotech. 7:218-233.
Singh, B., Usha, K. (2003). Salicylic acid induced physiological and biochemical changes in wheat seedlings under water stress. Plant Growth Regul. 39:137-141.

Singh, K. N., Prakash, J., Agrawal, A. K. Singhal, G. S. (1984). Interaction of herbicides with pea chloroplasts. Z. Naturforsch.39:464-467.

Wilcut, J.W., York, A.C., Wehtje, G.R. (1994). The control and interaction of weeds in peanut. Rev. Weed Sci. 6:177-205.

Xiang, M., Chen, S., Wang, L., Dong, Z., Huang, J., Zhang, Y., Strasser, R.J. (2013). Effect of vulculic acid produced by Nimbya alternantherae on the photosynthetic apparatus of Alternanthera philoxeroides. Plant Physiol. Biochem. 65:81-88.

Yu, J., Admedna, M., Goktepe, I. (2007). Peanut protein concentrate: production and functional properties as affected by processing. Food Chem. 103:121-129.

Yu, Q., Friesen, L.J.S., Zhang, X.Q., Powles, S.B. (2004).Tolerance to acetolactate synthase and acetyl-coenzyme A carboxylase inhibiting herbicides in Vulpia bromoides is conferred by two co-existing resistance mechanisms. Pest. Biochem. Physiol. 78: 21-30.

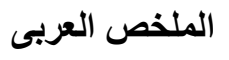

هدف الدر اسة الحالية تقييم محتويات البروتين و عديدات الببتيد polypeptides لصنفين من أوراق الفول السوداني ( (hypogaea L. cv. Giza 5 and Giza 6

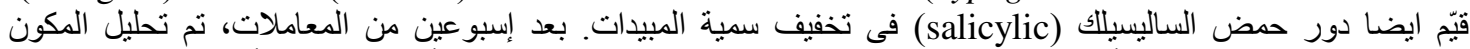

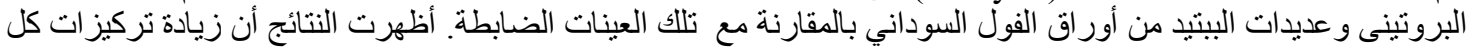

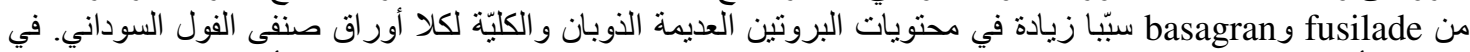

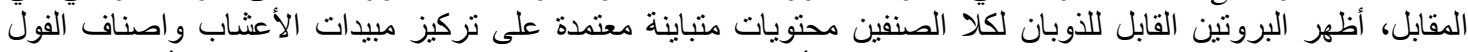

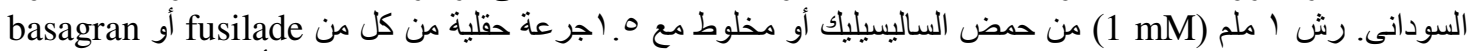

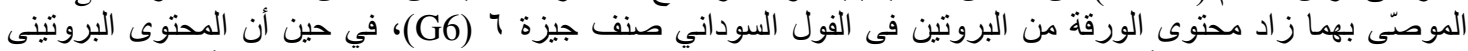

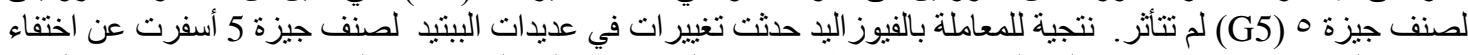

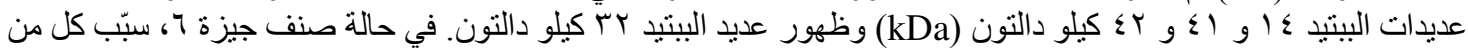

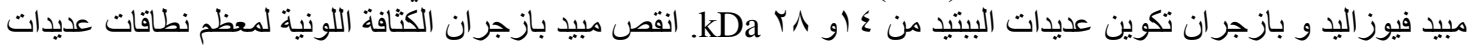

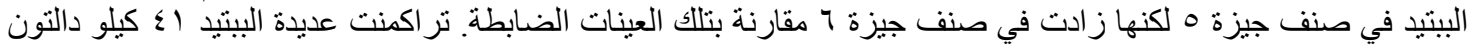
نتجية المعاملة المشتركة من حمض الساليسيليك ومبيدات الأعثاب. 